\title{
I 200 years of decadal-scale variability of Mediterranean vegetation and climate at Pantelleria Island, Italy
}

\author{
Camilla Calò, ' Paul D Henne,' Patricia Eugster, ${ }^{2}$ \\ Jacqueline van Leeuwen, ' Adrian Gilli, ${ }^{3}$ Yvonne Hamann, ${ }^{3}$ \\ Tommaso La Mantia, ${ }^{4}$ Salvatore Pasta, ${ }^{4}$ Elisa Vescovi ' and Willy Tinner'
}

\begin{abstract}
A new sedimentary sequence from Lago di Venere on Pantelleria Island, located in the Strait of Sicily between Tunisia and Sicily was recovered. The lake is located in the coastal infra-Mediterranean vegetation belt at $2 \mathrm{~m}$ a.s.l. Pollen, charcoal and sedimentological analyses are used to explore linkages among vegetation, fire and climate at a decadal scale over the past I200 years. A dry period from AD 800 to I000 that corresponds to the 'Medieval Warm Period' (WMP) is inferred from sedimentological analysis. The high content of carbonate recorded in this period suggests a dry phase, when the ratio of evaporation/precipitation was high. During this period the island was dominated by thermophilous and drought-tolerant taxa, such as Quercus ilex, Olea, Pistacia and Juniperus. A marked shift in the sediment properties is recorded at AD 1000, when carbonate content became very low suggesting wetter conditions until AD 1850-1900. Broadly, this period coincides with the 'Little Ice Age' (LIA), which was characterized by wetter and colder conditions in Europe. During this time rather mesic conifers (i.e. Pinus pinaster), shrubs and herbs (e.g. Erica arborea and Selaginella denticulata) expanded, whereas more drought-adapted species (e.g. Q. ilex) declined. Charcoal data suggest enhanced fire activity during the LIA probably as a consequence of anthropogenic burning and/or more flammable fuel (e.g. resinous Pinus biomass). The last century was characterized by a shift to high carbonate content, indicating a change towards drier conditions, and re-expansion of $Q$. ilex and Olea. The post-LIA warming is in agreement with historical documents and meteorological time series. Vegetation dynamics were co-determined by agricultural activities on the island. Anthropogenic indicators (e.g. Cerealiatype, Sporormiella) reveal the importance of crops and grazing on the island. Our pollen data suggest that extensive logging caused the local extinction of deciduous Quercus pubescens around AD 1750.
\end{abstract}

\section{Keywords}

central Mediterranean, fire history, 'Little Ice Age' (LIA), 'Medieval Warm Period' (MWP), Pinus pinaster, Quercus ilex, Quercus pubescens, vegetation history

Received 3 July 2012; revised manuscript accepted I0 May 2013

\section{Introduction}

Few palaeoenvironmental reconstructions are available from near the Mediterranean coast that combine independent proxies for climate, vegetation, and fire at high temporal resolution. Consequently, it is difficult to ascribe the importance of climatic change for vegetation dynamics in heavily disturbed Mediterranean ecosystems. Furthermore, instrumental records do not extend through transitions between interesting climatic anomalies during the last millennium such as the 'Medieval Warm Period' (MWP) and 'Little Ice Age' (LIA). To fill these gaps we carried out a multiproxy palaeoclimatic and palaeoecological investigation at Lago di Venere, Pantelleria for the last 1200 years

Pantelleria is a small island $\left(83 \mathrm{~km}^{2}\right)$ in the central Mediterranean Sea, $70 \mathrm{~km}$ east of Tunisia and $100 \mathrm{~km}$ southwest of Sicily (Figure 1). The island has a small lake of volcanic origin, Lago di Venere, that established c. 50,000 years ago (Civetta et al., 1988). Lago di Venere is one of very few natural, low-elevation lakes near the Mediterranean coast. This rarity, in combination with the rapid accumulation of carbonate-rich sediments makes Lago di Venere a prime target for palaeoenviromental and palaeoclimatic studies.

No information is available from Pantelleria about long-term vegetation history, or how vegetation was impacted by climate and human disturbances such as grazing and fire. Vegetation change in the Mediterranean region is widely ascribed to changing moisture availability and human disturbance (Roberts et al., 2011). For example, arboreal vegetation expanded at low elevation near Pantelleria in Sicily and Malta when moisture availability increased about 7000 cal. yr BP (Calò et al., 2012; Djamali et al., 2013; Noti et al., 2009; Tinner et al., 2009). However, after the Neolithic period (c. $5000 \mathrm{BC}$ ) the largest changes in vegetation near the central Mediterranean coast relate to human disturbance and an increase in fire activity (Bisculm et al., 2012; Calò et al., 2012; Carroll et al., 2012; Leighton, 1999; Tinner et al., 2009). The most intense period of forest destruction (e.g. conversion of woodlands to sclerophyllous maquis) occurred during the Iron Age, Greek or Roman times (c. $900 \mathrm{BC}-\mathrm{AD}$ 200). During early

\footnotetext{
'Institute of Plant Sciences and Oeschger Centre for Climate Change Research, University of Bern, Switzerland

${ }^{2}$ University of Potsdam, Institute of Earth and Environmental Science, Germany

${ }^{3}$ Geological Institute, ETH Zurich, Switzerland

${ }^{4}$ Department SAF, University of Palermo, Italy
}

\section{Corresponding author:}

Camilla Calò, Altenbergrain 21, 3013 Bern, Switzerland.

Email: calo.camilla@gmail.com 


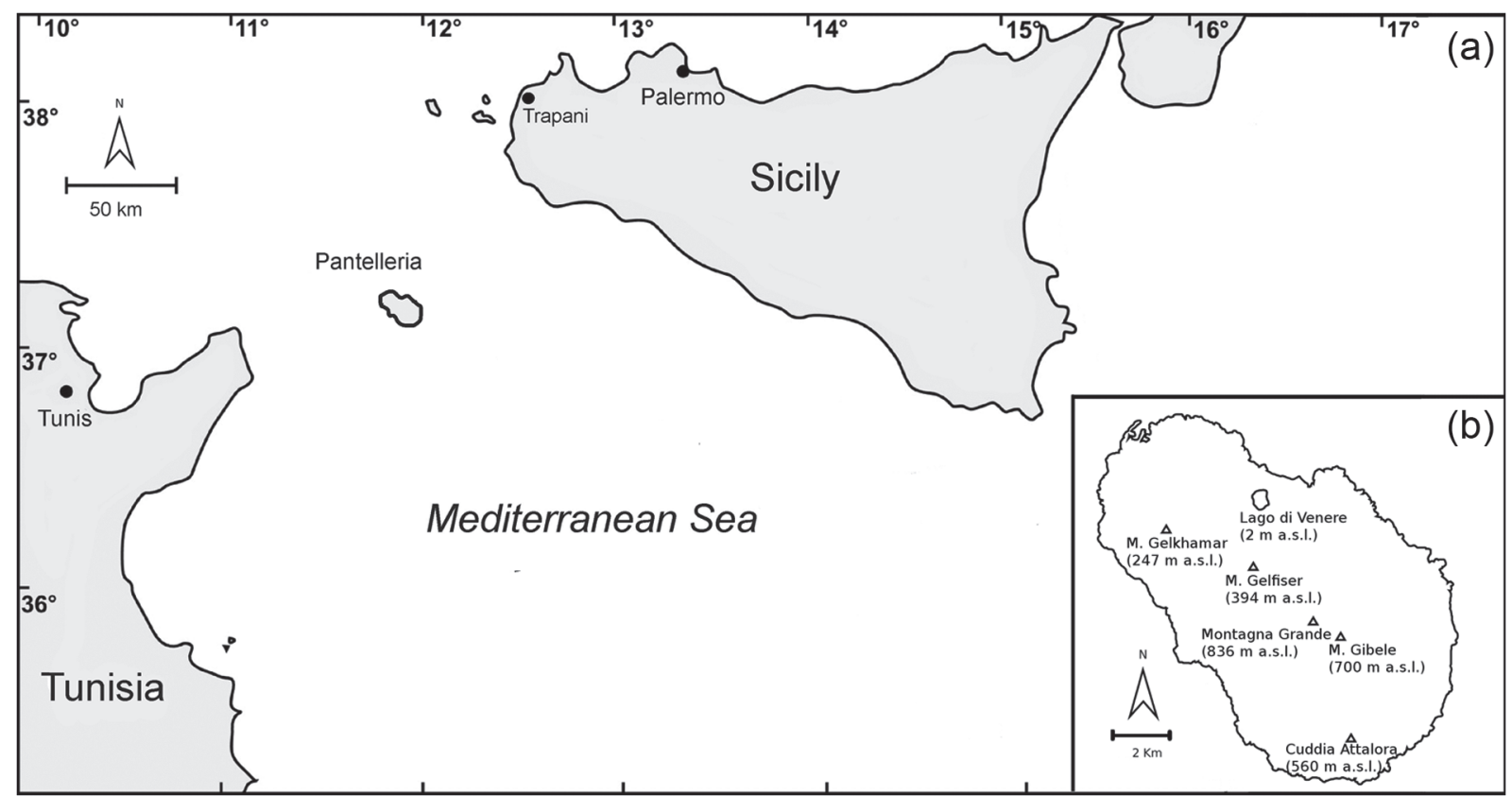

Figure I. (a) Map showing the position of Pantelleria Island in the Sicily channel of the Mediterranean Sea. (b) Detailed map of Pantelleria Island with the location of Lago di Venere and major peaks.

Medieval times (AD 700-800), pollen records suggest land-use intensification in the Mediterranean realm (Atherden and Hall, 1999; Colombaroli et al., 2007; Sobrino et al., 2005). Constant grazing and frequent burning eliminated forests and favoured the expansion of garrigue and maquis (Henne et al., 2013; Tinner et al., 2009). Human disturbance in the Mediterranean is often related to burning (Colombaroli et al., 2008; Moreno et al., 1998; Vannière et al., 2011), but the lack of information about palaeo-fire activity on Pantelleria impedes an assessment of the long-term relevance of fire for the island.

We used a multiproxy approach with (1) x-ray fluorescence (XRF) to develop calcium content of Lago di Venere sediments as a proxy for changes in moisture availability, (2) pollen for inferring vegetation history and (3) charcoal analyses for reconstructing past fire activity. The palaeoclimatic record is then used to disentangle climatic and anthropogenic causes of vegetational and fire-regime changes. The reconstruction, with decadal-scale resolution, offers new insights into the linkages among climate change, land use and vegetation dynamics over the last millennium in the central Mediterranean.

\section{Environmental settings}

The basin 'Lago di Venere' (also known as 'Specchio di Venere' or

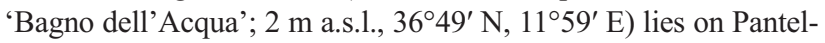
leria Island, which is located in the centre of the rift zone of the Strait of Sicily, between Tunisia and Sicily (Figure 1a). Pantelleria is the top of a large late-Quaternary volcano, mainly formed by volcanic rocks erupted about 324,000 yr BP (Mahood and Hildreth, 1986). The island has a surface of $83 \mathrm{~km}^{2}$ and is predominantly formed by acid and silicic vulcanites (pantellerites and trachytes: Aiuppa et al., 2007). The shape is elliptic (orientation NW-SE), with a coastline $51.5 \mathrm{~km}$ long. The highest point on the island is Montagna Grande (836 m a.s.1.), an inactive volcano, that along with Monte Gibele (700 m a.s.1.) and Cuddia Attalora (560 m a.s.1.), forms the mountainous southeastern part of Pantelleria (Figure 1b). The northwestern part of the island is mostly characterized by hills (e.g. Mt Gelfiser 394 m a.s.l. and Mt Gelkhamar 247 m a.s.1.).

Lago di Venere is an endorheic saline basin within a calderic depression that formed approximately 50,000 years ago during the 'Green Tuff' ignimbrite eruption (Civetta et al., 1988). The lake is about $450 \mathrm{~m}$ long and $350 \mathrm{~m}$ wide, with a maximum water depth of c. $12.5 \mathrm{~m}$. There is no outlet or inlet, thus rainfall and hydrothermal springs are the only water inputs (Aiuppa et al., 2007). The climate of Pantelleria is typically Mediterranean, characterized by hot, dry summers and mild winters that provide most of the annual rainfall (Figure 2). Mean July temperature (1961-1990) at $170 \mathrm{~m}$ a.s.1. is $25^{\circ} \mathrm{C}$, mean January temperature $12^{\circ} \mathrm{C}$ and mean annual temperature $18^{\circ} \mathrm{C}$, while mean annual precipitation is $485 \mathrm{~mm}$ (Figure 2). More than $70 \%$ of the total precipitation falls in the period from October to February (Gianguzzi, 1999). The pronounced summer drought is not the only factor influencing the vegetation on the island: salty winds are recorded 337.5 days per year and cause severe water stress on vegetation because of increased transpiration losses. However, the wet winds that hit Montagna Grande (836 m a.s.1.) often induce fog on the uppermost part of the island (Gianguzzi, 1999), where the microclimate is milder and wetter.

Pantelleria is characterized by high plant species richness, with the presence of several endemic species such as Helichrysum errerae Tin., Limonium cosyrense (Guss.) O. Kuntze, Matthiola incana (L.) R. Br. subsp. pulchella (P. Conti) Greuter \& Burdet in the coastal zone, and Limonium secundirameum (Lojac.) along the shore of Lago di Venere (Gianguzzi, 1999). Three main bioclimatic belts have been identified on the island (Gianguzzi, 1999). The infra-Mediterranean semiarid belt (0-200 $\mathrm{m}$ a.s.1.), prone to salt-spray and aridity, is mainly characterized by maquis (Juniperus turbinata Guss. and Periploca angustifolia Labill.). ThermoMediterranean (evergreen) vegetation covers most of the island (200-450 $\mathrm{m}$ a.s.1.). This zone includes relict forest communities of Quercus ilex as well as remnants of coastal Pinus halepensis Mill. forest in the south, where warm African winds constantly hit the island. In the evergreen-broadleaved $Q$. ilex-dominated forests, Erica arborea L., Arbutus unedo L., Lonicera implexa Aiton, Pistacia lentiscus L., Daphne gnidium L., Smilax aspera L. and Phillyrea latifolia L. co-occur. Where recently disturbed, the thermo-mediterranean vegetation type is characterized by Pistacia lentiscus, Euphorbia dendroides L., Olea europaea L. var. sylvestris (Mill.) Lehr. and Teucrium fruticans L. Cooler and moister environmental conditions characterize the meso-mediterranean 
Temperature ${ }^{\circ} \mathrm{C}$

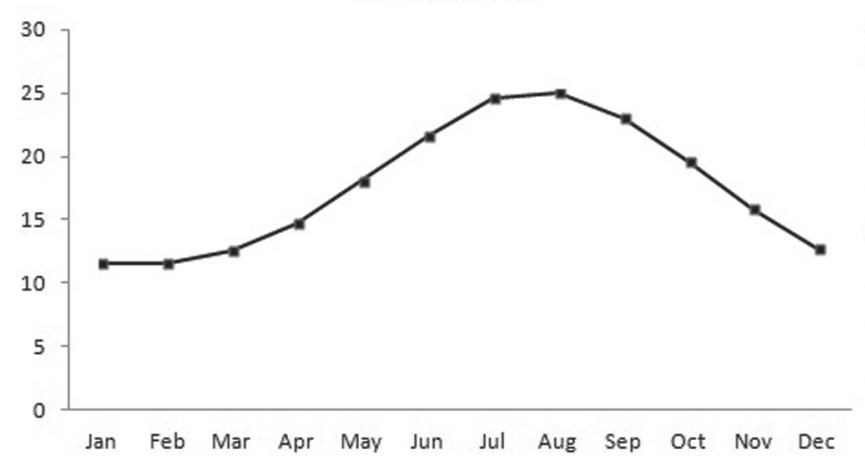

Precipitation average $(\mathrm{mm})$

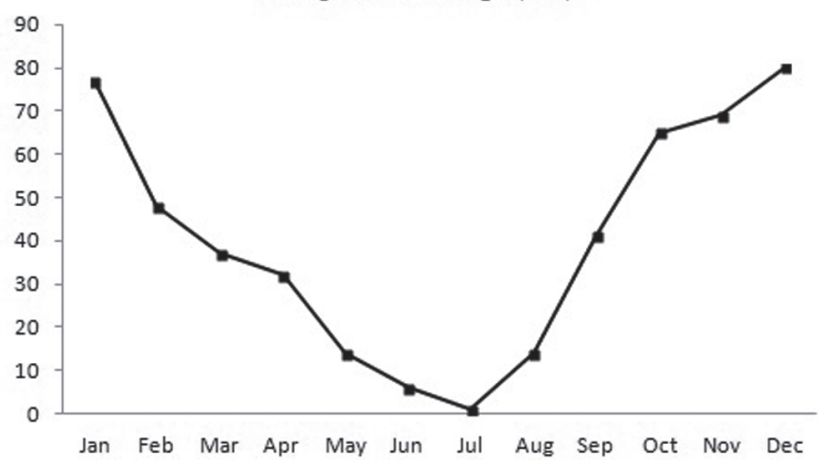

Figure 2. Average temperature and precipitation recorded at the weather station on Pantelleria Island at $170 \mathrm{~m}$ a.s.l. during the period |97|-2000.

Data source: http://www.klimadiagramme.de/Europa/pantelleria.html

Table I. Radiocarbon dates. The mid-point of the calibrated I $\sigma$ age range was used for building the age model.

\begin{tabular}{llllrr}
\hline Laboratory code & Core & Depth $(\mathrm{cm})$ & Material & ${ }^{14}$ C age (yr BP) & Cal.yr AD \\
\hline Poz-30194 & VEB & $588-590$ & Charcoal, leaf, wood & $685 \pm 30$ & $1329 \pm 52$ \\
Poz-30195 & VEB & $989-991$ & Wood & $1185 \pm 52$ & $833 \pm 52$ \\
\hline
\end{tabular}

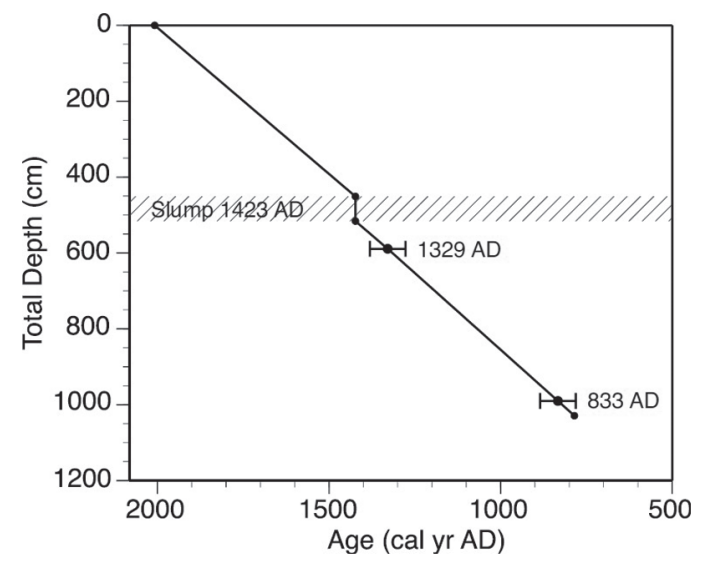

Figure 3. Radiocarbon dating of the sediments of Lago di Venere. Error bars show the $I \sigma$ error range of the calibrated ${ }^{14} \mathrm{C}$ dates. Black dots show the midpoint of the $I \sigma$ error range, and the sampling depth of the dated material.The depth-age model was produce by linear interpolation of the dated levels.

vegetation of the top of Montagna Grande ( $836 \mathrm{~m}$ a.s.1.), where the mean annual temperature is below $16^{\circ} \mathrm{C}$. In this area, Pinus pinaster grows in association with Myrtus communis, Erica arborea and Arbutus unedo, partially covered by mosses and lichens. It is unclear whether deciduous trees ever populated the island naturally. Reliable sources report the presence of evergreen and deciduous oaks on Pantelleria Island, with timber suitable for ship building (Furia, 1863; Smyth, 1824). Historical documents also mention Castanea sativa Mill. (D'Avezac, 1848; Furia, 1863; Smyth, 1824), of which a few scattered individuals still remain, and even Fagus sylvatica L. (Furia, 1863).

\section{Material and methods}

\section{Coring and dating}

Two parallel cores (VEA and VEB) were extracted from Lago di Venere in summer 2008 with a modified Livingstone corer $4.8 \mathrm{~cm}$ in diameter (Lang, 1994). The cores were recovered from the deepest lake basin in $11 \mathrm{~m}$ water depth. The cores were visually correlated using prominent lithological layers to produce a continuous sedimentary sequence. The master core contains mostly sections from core VEB and was in total $10.29 \mathrm{~m}$. The sediments of core VEB between 516 and $451 \mathrm{~cm}$ show various degrees of folding and therefore have been interpreted as a slump.

Terrestrial plant macrofossils (leaf, wood and charcoal) from core VEB were used for Accelerator Mass Spectrometry (AMS) analyses to infer radiocarbon dates (Table 1). The dates were converted to calibrated ages (cal. yr AD) using Calib version 6.0 with the radiocarbon age calibration set Intcal09 (Reimer et al., 2009). The two ${ }^{14} \mathrm{C}$ dates were linearly interpolated and extrapolated to provide sample ages (Figure 3 ) revealing a basal age in the master core of 785 cal. yr AD. The depth-age model dates the slump around 1423 cal. yr AD (Figure 3). As this slump deposit does not contain paleoclimatic and palaeovegetational information, this section was not used for the discussion of the climate and vegetation history.

\section{Pollen and microscopic charcoal}

Subsamples of $1 \mathrm{~cm}^{3}$ of sediment were taken every $8 \mathrm{~cm}$ for pollen and microscopic charcoal analyses. Standard procedures for glycerin samples (Moore et al., 1991) were followed in order to prepare a total of 95 sediment samples. Lycopodium tablets were added to estimate pollen concentrations (grains $/ \mathrm{cm}^{3}$ ) and influx (grains $/ \mathrm{cm}^{2}$ per yr; Stockmarr, 1971). Pollen and spore identification followed keys (e.g. Beug, 2004; Moore et al., 1991; Punt, 1976; Van Geel, 1986), pollen atlases (e.g. Reille, 1992) and the reference collection of the Institute of Plant Sciences of the University of Bern. Pollen preservation is good for the entire record. The minimum number of pollen grains counted per slide was $\mathrm{c}$. 250 , excluding pollen of water plants and spores. The pollen diagram was subdivided into local pollen assemblage zones (LPAZ) using the zonation method of optimal partitioning (Birks and Gordon, 1985). The number of statistically significant zones was inferred with the program BSTICK following the broken-stick approach (Bennett, 1996). Microscopic charcoal particles longer than $10 \mu \mathrm{m}$ were counted in pollen slides and used to calculate charcoal influx (particles $/ \mathrm{cm}^{3}$ per yr; Finsinger and Tinner, 2007; Stockmarr, 1971; Tinner and $\mathrm{Hu}, 2003$ ). The trend of the most important pollen types has been determined by smoothing with a five-point moving average. 


\section{Sedimentology and XRF core scanning}

The master core was sedimentologically described following Schnurrenberger et al. (2003). An Avaatech ${ }^{\mathrm{TM}} \mathrm{x}$-ray fluorescence (XRF) core scanner was applied to the master sections to infer changes in the elemental composition of the sediment (For details see Richter and van der Gaast, 2006). The measurements were conducted continuously using standard settings (voltage: $10 \mathrm{kV}$; current: $200 \mu \mathrm{A}$, count time: $20 \mathrm{~s}$ ) with stepwise sampling of 1 $\mathrm{cm}$. Powder X-ray diffraction (XRD) measurements with a Bruker AXS D8 Advance allowed the determination of the major minerals.

\section{Results}

\section{Pollen stratigraphy}

The pollen and charcoal record (Figures 4, 5) is subdivided into three statistically significant local pollen assemblage zones (VEB1-3). Zone VEB1 (800-1000 cal. yr AD) is characterized by high percentages of arboreal taxa. The most important taxa are Olea, Quercus ilex-type and Pinus (from 20\% to 40\%). Quercus pubescens-type and Quercus suber-type are present, but with lower percentages (Figure 3). The shrub component is mostly formed by Erica arborea-type, Juniperus and Pistacia (up to 20\%). The herb sum (dominated by Artemisia, Poaceae and Rumex-type) remains low through the whole zone (Figure 4).

Zone VEB2 spans from AD 1000 to 1900 cal. yr. The main change is a prominent increase of Pinus percentages (up to 80\%) and the decrease of other arboreal taxa, such as Olea and $Q$. ilextype (Figure 4). The presence of $Q$. pubescens-type pollen is discontinuous. This taxon, after a first contraction, reappears from 1400 cal. yr AD and lasts until 1750 cal. yr AD. Shrub pollen increases in comparison to the preceding zone. E. arborea-type reveals a shift from $10 \%$ to $40 \%$ and Cistus percentages also increase. However, Pistacia and Juniperus decline. The sum of the herbs is low, although Rumex-type shows some peaks (Figure 4; 1090, 1180, and 1750 cal. $\mathrm{yr} \mathrm{AD}$ ).

VEB3 is a short zone that covers the last century (1890-2008 cal. yr AD). An important decrease of Pinus (from $80 \%$ to $20 \%$ ) and $E$. arborea-type (from $40 \%$ to $2 \%$ ) characterizes the whole zone. Q. ilex is the only taxon that shows an increase (up to $35 \%$; Figures 3, 4). Herbs remain very low, although two peaks (1900 and 1990 cal. yr AD) occur that are mainly formed by Rumex-type, Poaceae, Urtica dioica-type, Cerealia-type and Artemisia.

\section{Charcoal record}

Our charcoal data (Figure 4) show that from 800 to $1000 \mathrm{cal}$. yr AD (VEB1) no prominent microscopic charcoal peak occurs. Within the pollen zone VEB2 a first microscopic charcoal peak is registered at $1300 \mathrm{cal}$. yr AD $\left(151,350\right.$ particles $/ \mathrm{cm}^{2}$ per yr). Subsequently two minor peaks are recorded, at $1350 \mathrm{cal}$. $\mathrm{yr} \mathrm{AD}(50,150$ particles $/ \mathrm{cm}^{2}$ per yr) and at $1370 \mathrm{cal}$. yr AD $\left(70,200\right.$ particles $/ \mathrm{cm}^{2}$ per yr). The highest charcoal influx values occur at c. 1500 cal. yr AD $\left(194,600\right.$ particles $/ \mathrm{cm}^{2}$ per yr). Less pronounced charcoal peaks occur at $1580 \mathrm{cal}$. yr $\mathrm{AD}\left(115,400\right.$ particles $/ \mathrm{cm}^{2}$ per yr $)$ and at 1650 cal. yr $\operatorname{AD}\left(131,191\right.$ particles $/ \mathrm{cm}^{2}$ per yr). Subsequently, abundance of microscopic charcoal generally decreases and reaches low values during the last 50 years.

\section{Lithology and sediment composition}

The core consists of carbonatic gyttja, which is in certain intervals clearly laminated, as well as sections dominated by clastic sediments of various grain sizes and increased organic content. The litho-stratigraphic profile can be subdivided into five main units (Figure 4). Unit 1 (800-1000 cal. yr AD) consists of light carbonate laminations with a maximum thickness of $3 \mathrm{~mm}$ intercalated with darker, organic-rich lamina partly consisting of microbial threats. This is overlain by Unit $2(1000-1300 \mathrm{cal}$. yr AD) characterized by clastic sediment of clay, silt and sand size fraction, partly graded and sporadically containing volcanic pumice. Organic content is high. Unit 3 (1300-1400 cal. yr AD) is an interval of carbonate mud interrupted by dark sections rich in detritus. Unit 4 (1400-1650 cal. $\mathrm{yr} \mathrm{AD}$ ) is, like Unit 2 , dominated by clastic sediment with organic rests. The stratigraphically youngest Unit 5 consists of carbonate mud with increasing carbonate content towards the top. Part of Unit 5 is laminated, whereas some parts are homogenous with increased organic content.

XRD measurements indicate aragonite is the dominant carbonate mineral for the entire sedimentary record. Therefore, changes in Calcium $(\mathrm{Ca})$ abundance in the sediment correspond to variations in the amount of aragonite. We measured changes in $\mathrm{Ca}$ abundance using XRF (Figure 6). Although the Ca curve cannot be converted into absolute carbonate concentrations, the relative changes are a semi-quantitative indication of the varying carbonate content. Sedimentary content is high during two intervals, at the start of the record (c. 800-1000 cal. yr AD) and from c. $1850-1900 \mathrm{cal}$. $\mathrm{yr} \mathrm{AD}$ to the end of the record. Ca is generally low from 1000 to $1900 \mathrm{cal}$. yr AD, with somewhat higher values from 1300 to 1500 cal. yr AD (Figure 6).

\section{Interpretation and discussion}

\section{Sedimentology and climate}

The Lago di Venere sediment varies between light carbonate lamina and darker intervals dominated by detrital influx and rather higher organic content. These variations are well expressed in the Calcium (Ca) curve from the XRF measurements (Figure 6). The water analysis of several studies (Aiuppa et al., 2007; Cangemi et al., 2010; Duchi et al., 1994) documented a supersaturation of aragonite in the water column. Analysis of short sediment cores confirmed that aragonite is also very abundant in the surface sediments (Aiuppa et al., 2007). Therefore, it is likely that during dry intervals, a reduced lake volume increases the ionic concentration of the lake water favouring the precipitation of aragonite. In contrast, during wetter climatic phases more detrital input from the volcanic catchment is washed in, diluting the sedimentary carbonate content. Thus we interpret high $\mathrm{Ca}$ values as indicating drier intervals, and low $\mathrm{Ca}$ values as indicating wetter intervals (Figure 6). On this basis, our results record a dry interval from 800 to 1000 cal. $\mathrm{yr} \mathrm{AD}$ and increased moisture availability from 1000 to 1900 cal. yr AD, followed by a shift to drier conditions. During recent years the lake underwent seasonal lake-level fluctuations of several decimeters (Aiuppa et al., 2007), but also a general lowering of the lake level is observed since the 1960s (Duchi et al., 1994). Although the reason for this modern lake level lowering remains unclear, a drying trend would increase the evaporation/precipitation ratio, which would lead to increased formation of aragonite, and explain the high $\mathrm{Ca}$ values in the upper sediments (Figure 6).

\section{Vegetation history and climate}

Broadleaved evergreen trees $(Q$. ilex, Olea $)$ dominated the vegetation of the island forming forests from 800 to $1000 \mathrm{cal}$. yr AD (Figure 4). Shrubby communities mainly consisting of thermophilous taxa such as Pistacia and Juniperus, and heliophilous herbs such as Artemisia and Cichorioideae were probably also widespread. In the present vegetation, Juniperus turbinata mainly occurs in the infra-Mediterranean semi-arid coastal vegetation, whereas Olea and Pistacia are frequent in the thermo-Mediterranean belt of the island and $Q$. ilex in the thermo-Mediterranean 


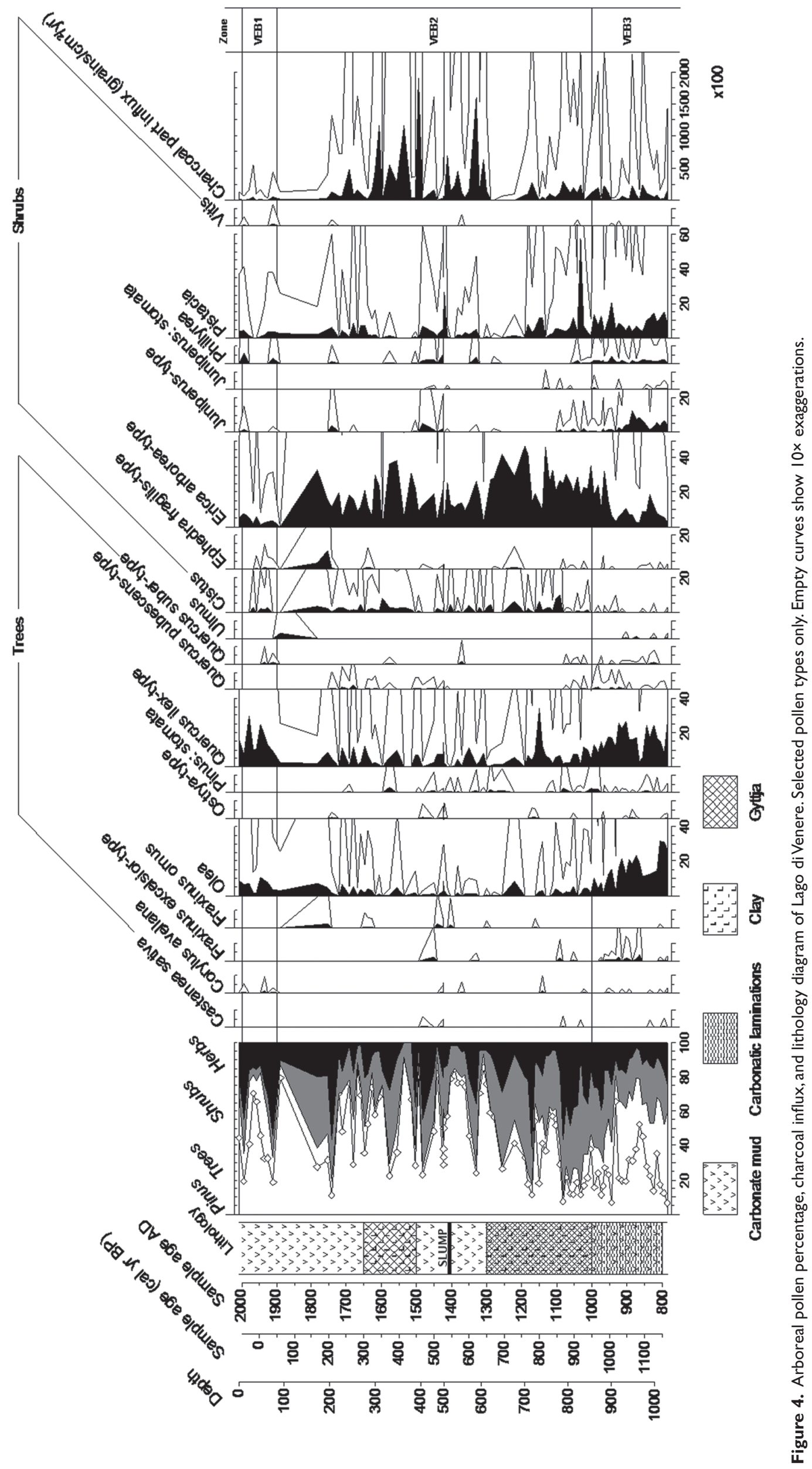




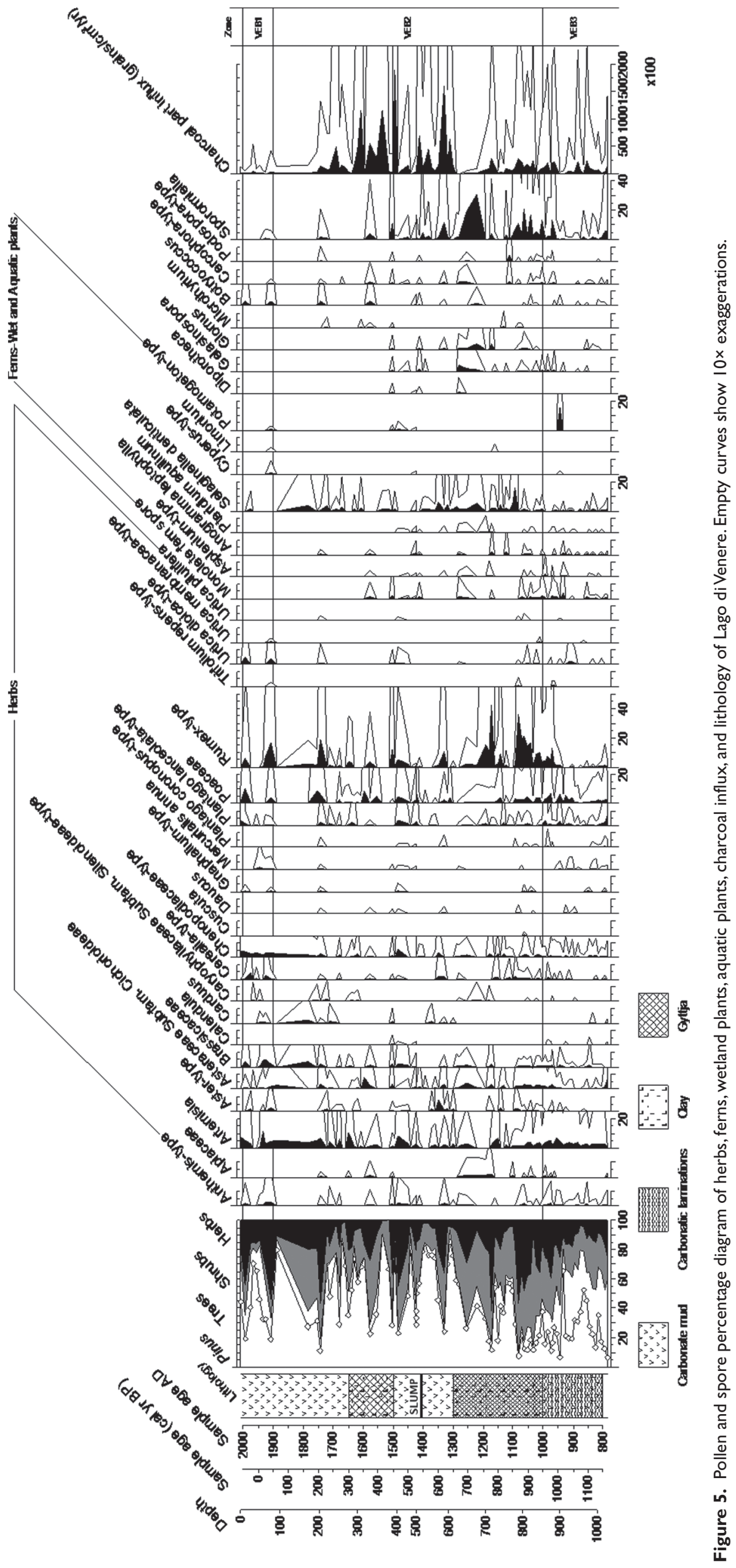




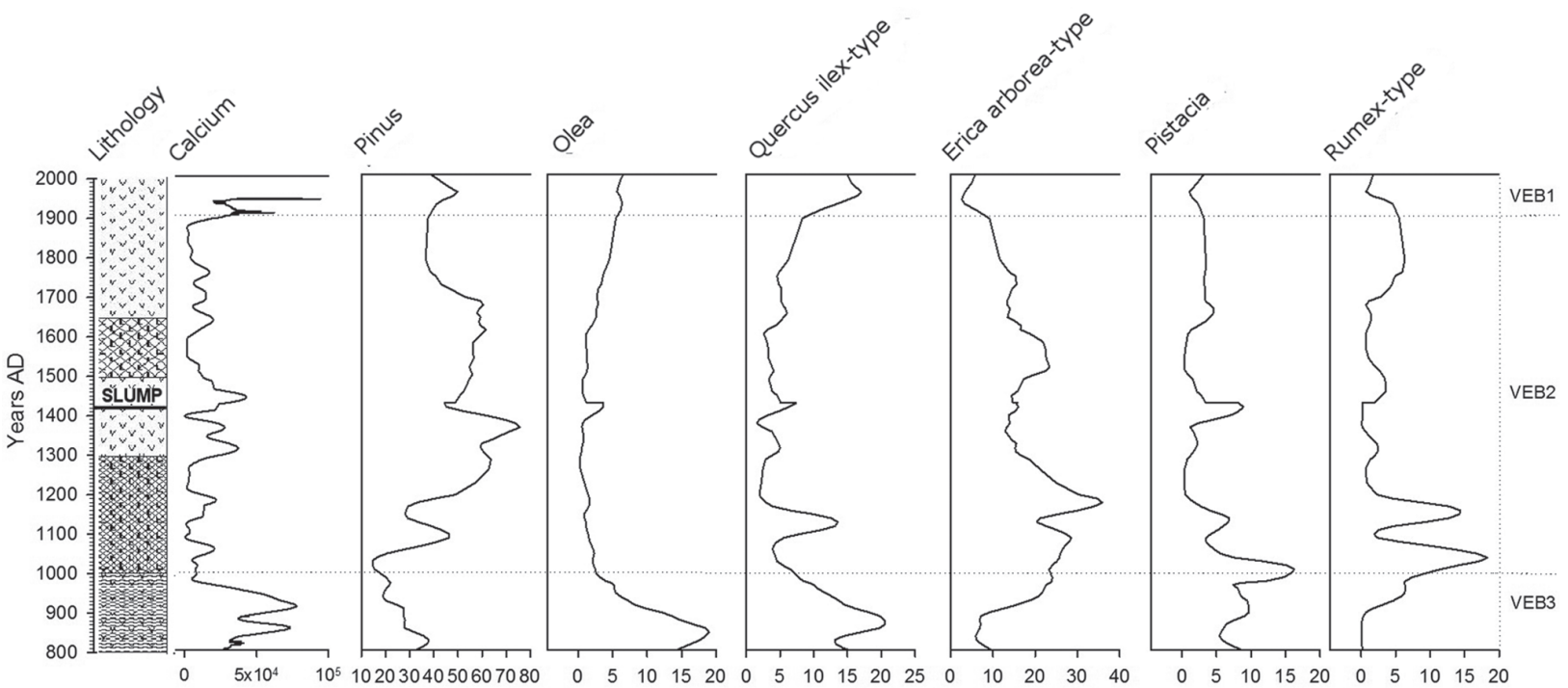

Figure 6. Smoothed curves of sediment calcium content, important pollen types, and lithology. Dotted lines show significant pollen zones. High calcium values correspond to drier intervals, low values to moister intervals.

and meso-Mediterranean belts. The vegetation was probably influenced by particularly dry summer conditions between 800 and 1000 cal. yr AD. Pollen-independent evidence for dry conditions comes from sedimentology. During the period 800-1000 cal. $\mathrm{yr} \mathrm{AD}$, an interval rich in carbonate layers occurred when drought-adapted taxa such as Q. ilex, Olea and Pistacia were abundant (Figure 6). This period roughly coincides with the 'Medieval Warm Period' (MWP) that in the Northern Hemisphere was characterized by higher temperatures, compared with those of the centuries that immediately preceded and followed it (Bradley et al., 2003). The MWP lasted between about 900 and 1300 $\mathrm{AD}$, however the timing has been demonstrated to vary geographically (Bradley and Jones, 1993; Bradley et al., 2003; Hughes and Diaz, 1994).

An important, statistically significant, change of vegetation (boundary LPAZ 1/2) occurred about 1000 cal. yr AD. Conifers and especially Pinus expanded, while broadleaved evergreen trees declined (Figure 4). Today, drought-adapted Pinus halepensis and more mesophilous Pinus pinaster both grow on the island. However, $P$. pinaster stands are far more abundant $(5.1 \%$ of total vegetation) than those of $P$. halepensis ( $0.3 \%$; Gianguzzi, 1999). Thus, Pinus pollen should predominantly (93\%) reflect an increase in $P$. pinaster. Similarly, relatively moisture-demanding $E$. arborea communities expanded, while the drought-tolerant maquis formed by Pistacia and Juniperus declined.

A link between Pinus expansion at 1000 cal. yr AD and changing climatic conditions is again supported by sedimentology. Calcium declined between 900 and $1000 \mathrm{cal}$. yr AD, and carbonate deposition remained low from 1000 to $1850 \mathrm{cal}$. yr AD (Figure 6). Thus, the vegetational change was probably driven by a climatic shift towards moister conditions before and during the 'Little Ice Age' (LIA). The age of the LIA is not very well constrained but the earliest evidence dates back to C. AD 1100-1200 in the European Alps (Holzhauser et al., 2005). We assume that enhanced rainfall and/or cooler conditions during the LIA increased moisture availability, thus promoting relatively moisture-demanding species (e.g. P. pinaster, E. arborea, Arbutus unedo, Rumex, Selaginella denticulata) at the expense of more xeric vegetation (e.g. Q. ilex, Olea europaea, Pistacia, Juniperus turbinata and Phillyrea; Figure 4). The $P$. pinaster expansion may also mean that in contrast to today's regime of relatively moist winters and very dry spring and summer seasons (Figure 2), warm-season moisture was more abundant during the LIA. P. pinaster shows better growth with an annual precipitation of at least $850 \mathrm{~mm} / \mathrm{yr}$, with at least $75 \mathrm{~mm}$ from May to September (Richardson and Rundel, 1998; Vidakovic and Soljan, 1991). Summer water stress is the main limiting factor for $P$. pinaster growth and because of its high stomatal sensitivity to soil water availability, this species is considered a droughtavoider (Bogino and Bravo, 2008; Chambel et al., 2007; Granier and Loustau, 1994; Picon et al., 1996). At present $P$. pinaster is restricted in a small area above $800 \mathrm{~m}$ a.s.l. on Pantelleria. However, the widespread presence of Pinus on the island from 1000 to 1900 cal. $\mathrm{yr} \mathrm{AD}$, may indicate that warm-season precipitation was more abundant during the LIA than at present.

Although lake sediment climate records from elsewhere in Italy lack the stratigraphic resolution needed to provide a detailed climate history from the last millennium (Luterbacher et al., 2012), our pollen and sedimentological data showing a shift from a dry MWP to a moist LIA is consistent with other evidence from the central and western Mediterranean. For example, surface temperatures near Southern Italy in Gulf of Taranto declined after 1000 cal. yr AD and remained low until 1800 cal. yr AD (Taricco et al., 2009). Lake records from Spain also show a dry MWP followed by a shift to moister conditions. However, dry conditions in Pantelleria lasted until $1000 \mathrm{cal}$. yr AD, whereas the dry MWP in Spain occurred between about 700 and 1400 cal. yr AD (MartinPuertas et al., 2008; Morellon et al., 2009; Moreno et al., 2012).

The last 100 years from 1900 to 2008 cal. yr AD are characterized by a re-expansion of broadleaved evergreen taxa. Local Olea populations seem to respond faster than $Q$. ilex. However by the end of the sequence, $Q$. ilex is the most important tree species. After 1900 cal. yr AD, communities formed by E. arborea declined while Pistacia re-expanded. The vegetation change fits well with the carbonate content that increased during the past 130 years, suggesting increased evaporation/precipitation ratios after the end of the LIA. This climatic trend is well documented also by the weather station in Pantelleria that reports an increase of $1^{\circ} \mathrm{C}$ of the annual mean temperature from 1951 to 1999 AD (Pirazzoli and Tomasin, 2003). Cooler conditions during the LIA on the island are also recorded in written sources that report the presence of stone wall structures built to gather snow on the top of Montagna Grande (Calcara, 1853). A shift to warmer and drier conditions at 
the end of the LIA is evident elsewhere in Southern Italy. For example, a historical precipitation series from Sicily reports an abrupt rainfall decrease after AD 1922 (Diodato, 2006). Similarly, the recurrence of drought events in Southern Italy increased during the 20th century relative to the previous 500 years, which may relate to a reduction in spring precipitation and increasing annual temperatures (Brunetti et al., 2006; Diodato, 2007; Diodato and Bellocchi, 2011). Drying at Pantelleria is also consistent with evidence for a general shift from the wettest period of the LIA during the 18th and 19th centuries in the western Mediterranean, to a drier 20th century (Nicault et al., 2008).

\section{Vegetation history and human impact}

Vegetational changes at Pantelleria were co-determined by agriculture and land use. Owing to its position in the middle of the Strait of Sicily, the island has been for millennia an important trade centre in the Mediterranean area. Despite chronological uncertainties, it has been hypothesized that the island was already frequented by $5900 \mathrm{BC}$, mainly to exploit obsidian (Whittle, 1996). Other archaeological sources indicate that Pantelleria was inhabited since the Bronze Age (i.e. 2000-1300 BC) and the most fertile areas were cultivated (Francaviglia and Piperino, 1987). Terraces and cisterns, introduced by Punic people (Baldassari, 2007), protected crops against the winds, provided new space for cultivation, reduced slope inclination and collected rainwater to supply the island's needs. Our new data cover the historical period that began with the Arabic domination of the island. Arabs conquered Pantelleria from the eastern Roman Empire in AD 835, colonizing the island and intensifying agriculture. The Arab period continued during the following centuries, but came to an abrupt end in $\mathrm{AD} 1123$, when the Normans conquered the island unifying it to Sicily and Southern Italy (D'Aietti, 1978). Afterwards, under Bourbon domination (AD 1713-1860), the intense production of capers, wine and charcoal was established, that has never been abandoned (D'Aietti, 1978).

Various indicators of human land use are recorded in the Lago di Venere sedimentary sequence. Grazing indicators including Anthemis-type, Cichorioideae, Aster-type, Brassicaceae, Artemisia-type, Caryophyllaceae, Carduus, as well as dung spores such as Cercophora, Podospora and Sporormiella, are distributed along the sequence and signal the continuous presence of humans on the island. Plantago lanceolata, Cerealia-type, and Mercurialis annua, suggest high levels of arable farming during the 20th century (c. 1900-1970, Figure 5). Of special interest is the strong increase of herbs $(>40 \%)$ during the period between c. 950 and 1100 cal. yr AD (Figure 5). This is probably the most long-lasting period of intense land-use activity. A link to climate change (e.g. drier and thus more open conditions) seems unlikely, since the expansion of Pinus and E. arborea point to increasing moisture availability. Instead, the abundance of Cerealia-type and Sporormiella point to intensification of farming at the end of the Arabic period and the onset of the Norman domination. From c. AD 1180 to 1280, the occurrence of Asteroideae, Apiaceae and Cerealia-type is synchronous to the most prominent peak of Sporormiella and to an increase of dung spores, such as Cercophora and Podospora (Figure 5). These data agree very well with historical sources that highlight the importance of agriculture and pasture in AD 1123 when Normans conquered Pantelleria (D'Aietti, 1978). Another significant episode of intensification of human activities occurred during the period AD 1450-1550, when frequent dung indicators are well linked to Cerealia-type, Plantago lanceolata, Mercurialis annua, Carduus, Cichorioideae and Anthemis-type. Pollen data (e.g. Cerealia-type) suggest high levels of arable farming during the 20th century (c. 1900-1970; Figure 5). During the first decades of the 20th century, viticulture was the main trade of the island and it is still important today (Di
Lorenzo and Sottile, 1990), which is reflected in the pollen record (sparse Vitis finds).

\section{Island fire history}

Changes in charcoal frequency suggest variable fire activity. In general fire activity was higher during the LIA (peaks from 1350 to $1650 \mathrm{cal}$. yr AD) than before and during the past century (Figure 5). This may suggest a fuel-limited ecosystem (Pausas and FernándezMuñoz, 2012), since the LIA was cooler and/or wetter than the periods before and afterwards. More likely, human control of fires and especially fire ignition may have determined the fire regime. In the Mediterranean region almost all fires are induced by humans and fire suppression or ignition is usually a key factor of fire regimes (e.g. Moreno et al., 1998). Nevertheless, climate significantly influences the occurrence of fire, for favourable fire-weather conditions affect flammability and influence the extent and intensity of fires once they are ignited (Vannière et al., 2011). Fuel-limited regimes have been reconstructed from Eski Acıgöl and Nar crater lakes in Turkey (Turner et al., 2008), whereas in the western and central Mediterranean, usually under moister conditions, fires were favoured by drier conditions (Tinner et al., 2009; Vannière et al., 2011).

After repeated fire disturbance Mediterranean ecosystems can undergo regressive succession towards a Cistus-dominated garrigue with Pteridium aquilinum (Chiappini, 1985; Rühl, 2003). For example, after burning, Juniperus communities are often replaced by Cistus creticus, C. salvifolius and C. monspeliensis (Gianguzzi, 1999). These shrubs and ferns are well recorded, especially Cistus which replaced Juniperus at around $1100 \mathrm{cal}$. yr AD (onset of VEBA2 and date of Norman conquest). Together with the increase of open spaces (pollen of herbs) and human indicators (e.g. Cerealia-type, Sporormiella), this shift suggests increased anthropogenic fire activity (Figure 5). Fire impact on the environment is also suggested by the sparse presence of Gelasinospora, the spore of a fungus growing on charcoal (Figure 5). Thus, the overall increase of Cistus spp. between 1000 and 1900 cal. yr AD may relate to increasing fire disturbance, not the climatic effects of the LIA.

Wood was constantly cut on Pantelleria to obtain timber, charcoal and firewood from the Norman period onward (11th century AD; D'Aietti, 1978). A consequence of extensive logging and burning in Pantelleria was the extinction of deciduous Quercus (probably Q. pubescens) c. $1750 \mathrm{cal}$. yr AD. Although this species is not currently present on the island, it was broadly used for shipbuilding purposes (Furia, 1863). Charcoal influx shows a decrease in the last pollen zone, when forests partly recovered. Ecological estimations point to a strong decline of cultivated land during the past century (from $81.6 \%$ to $28.1 \%$; Rühl, 2003), however, our pollen record suggests that open, unforested land during the past century was not significantly reduced, if compared with the past 800 years of vegetation history.

\section{Conclusions}

Our new combined record of vegetation and climate from Pantelleria Island demonstrates that small changes in moisture availability during the last 1200 years had a major impact on vegetation dynamics in a coastal Mediterranean ecosystem that was also strongly impacted by human land use. Low moisture availability before 1000 cal. yr AD favoured drought-tolerant Pistacia, Juniperus turbinata, Quercus ilex and Olea europaea during the MWP, whereas increased moisture availability allowed relatively mesophilous species including Pinus pinaster, Erica arborea, and Selaginella denticulate to expand between 1000 and 1900 cal. yr AD during the LIA. Droughtadapted species re-expanded during the 20th century as annual 
temperatures and drought intensity increased in Southern Italy. Although climatic changes during the last 1200 years elicited significant changes in vegetation on Pantelleria, these changes were small in comparison with projected reductions in moisture availability by the end of the 21 st century. For example, annual temperatures in southern Italy increased c. $1^{\circ} \mathrm{C}$ from the latest cool, moist period of the LIA to the middle of the 20th century (Brunetti et al., 2006; Diodato, 2007), whereas regional climate models project increased drought stress and annual temperature increases of $3-4^{\circ} \mathrm{C}$ (Gao and Giorgi, 2008). Therefore, our results showing that vegetation on Pantelleria was highly sensitive to minor climatic changes during the MWP and LIA, even under rather intense land-use activities imply that vegetation on Pantelleria may respond quickly and significantly to climatic changes anticipated for this century.

\section{Acknowledgements}

We are grateful to W Tanner, F Policarpo and P Miceli for logistical and practical help during the field work. We thank also the regional forest service (Azienda Regionale Foreste Demaniali) for providing permission to core the lake.

\section{Funding}

The Swiss National Science Foundation (grant PP00P2-114886) funded this research.

\section{References}

Aiuppa A, D'Alessandro W, Gurrieri S et al. (2007) Hydrologic and geochemical survey of the lake 'Specchio di Venere' (Pantelleria island, Southern Italy). Environmental Geology 53: 903-913.

Atherden M and Hall J (1999) Human impact on vegetation in the White Mountains of Crete since AD 500. The Holocene 9: 183-193.

Baldassari R (2007) I porti e gli approdi di Pantelleria dall'età punica al tardo antico: Considerazioni e analisi dei materiali rinvenuti. In: Marazzi M and Tusa S (eds) Pantelleria. Salerno: Editrice Gaia, pp. 29-42.

Bennett KD (1996) Determination of the number of zones in a biostratigraphical sequence. New Phytologist 132: 155-170.

Beug H-J (2004) Leitfaden der Pollenbestimmung für Mitteleuropa und angrenzende Gebiete, Munich: Verlag Dr. Friedrich Pfeil.

Birks HJB and Gordon AD (1985) Numerical Methods in Quaternary Pollen Analysis. Orlando: Academic Press.

Bisculm M, Colombaroli D, Vescovi E et al. (2012) Holocene vegetation and fire dynamics in the supra-mediterranean belt of the Nebrodi Mountains (Sicily, Italy). Journal of Quaternary Science 27: 687-698.

Bogino SM and Bravo F (2008) Growth response of Pinus pinaster Ait. to climatic variables in central Spanish forests. Annals of Forest Science 65: 506-506.

Bradley RS and Jones PD (1993) 'Little Ice Age' summer temperature variations: Their nature and relevance to recent global warming trends. The Holocene 3: 367-376.

Bradley RS, Hughes MK and Diaz HF (2003) Climate in medieval time. Science 302: 404-405.

Brunetti M, Maugeri M, Monti F et al. (2006) Temperature and precipitation variability in Italy in the last two centuries from homogenised instrumental time series. International Journal of Climatology 26: 345-381.

Calcara P (1853) Descrizione dell'isola di Panteleria. Atti dell' Accademia di Scienze e Lettere di Palermo 2, 44 pp.

Calò C, Henne PD, Curry B et al. (2012) Spatio-temporal patterns of Holocene environmental change in southern Sicily. Palaeogeography, Palaeoclimatology, Palaeoecology 323-325: 110-122.

Cangemi M, Bellanca A, Borin S et al. (2010) The genesis of actively growing siliceous stromatolites: Evidence from Lake Specchio di Venere, Pantelleria Island, Italy. Chemical Geology 276: 318-330.

Carroll FA, Hunt CO, Schembri PJ et al. (2012) Holocene climate change, vegetation history and human impact in the Central Mediterranean: Evidence from the Maltese Islands. Quaternary Science Reviews 52: 24-40.

Chambel MR, Climent J and Alía R (2007) Divergence among species and populations of Mediterranean pines in biomass allocation of seedlings grown under two watering regimes. Annals of Forest Science 64: 87-97.

Chiappini M (1985) Guida alla flora pratica della Sardegna. C. Delfino.

Civetta L, Cornette Y, Gillot P et al. (1988) The eruptive history of Pantelleria (Sicily Channel) in the last $50 \mathrm{ka}$. Bulletin of Volcanology 50: 47-57.
Colombaroli D, Marchetto A and Tinner W (2007) Long-term interactions between Mediterranean climate, vegetation and fire regime at Lago di Massaciuccoli (Tuscany, Italy). Journal of Ecology 95: 755-770.

Colombaroli D, Vannière B, Emmanuel C et al. (2008) Fire-vegetation interactions during the Mesolithic-Neolithic transition at Lago dell'Accesa, Tuscany, Italy. The Holocene 18: 679-692.

D'Aietti A (1978) Il libro dell'isola di Pantelleria. Milano: Trevi Editore.

D'Avezac M (1848) L'univers pittoresque. Histoire et description de tous les peuples, de leurs religion, moeurs, coutumes, industries. Paris: Firmin Didot Frêres.

Di Lorenzo R and Sottile I (1990) Aspetti e problemi della viticoltura dell'isola di Pantelleria. Agricoltura 209-210: 94-97.

Diodato N (2006) A 425-year precipitation history from documentary weather anomalies and climate records at Palermo-Astronomical Observatory (Sicily, Italy). PAGES News 14: 34-35.

Diodato N (2007) Climatic fluctuations in southern Italy since the 17th century: Reconstruction with precipitation records at Benevento. Climatic Change 80: 411-431.

Diodato N and Bellocchi G. (2011) Historical perspective of drought response in central-southern Italy. Climate Research 49: 189-200.

Djamali M, Gambin B, Marriner N et al. (2013) Vegetation dynamics during the early to mid-Holocene transition in NW Malta, human impact versus climatic forcing. Vegetation History and Archaeobotany DOI: 2010.1007/ s00334-00012-00380-00330.

Duchi V, Campana ME, Minissale A et al. (1994) Geochemistry of thermal fluids on the volcanic isle of Pantelleria, southern Italy. Applied Geochemistry 9: 147-160.

Finsinger W and Tinner W (2007) Pollen and plant macrofossils at Lac de Fully (2135 m a.s.1.): Holocene forest dynamics on a highland plateau in the Valais, Switzerland. The Holocene 17: 1119-1127.

Francaviglia V and Piperino M (1987) La reparation et la provenance de 1' obsidienne archaeologique de la Grotta dell'Uzzo et de Monte Cofano (Sicile). Revué d'Archéométrie 11: 31-39.

Furia B (1863) Memoria sulla posizione agraria silvana e commerciale dell 'isola di Pantelleria e sulla possibilità di costruirsi un porto. Palermo: Stamperia Sociale Macoclin Carini e Caronna.

Gao XJ and Giorgi F (2008) Increased aridity in the Mediterranean region under greenhouse gas forcing estimated from high resolution simulations with a regional climate model. Global and Planetary Change 62: 195-209.

Gianguzzi L (1999) Vegetazione e bioclimatologia dell'isola di Pantelleria (Canale di Sicilia). Braun-Blanquetia 22: 1-70.

Granier A and Loustau D (1994) Measuring and modelling the transpiration of a maritime pine canopy from sap-flow data. Agricultural and Forest Meteorology 71: 61-81.

Henne PD, Elkin C, Colombaroli D et al. (2013) Impacts of changing climate and land use on vegetation dynamics in a Mediterranean ecosystem: Insights from paleoecology and dynamic modeling. Landscape Ecology DOI: $2010.1007 / \mathrm{s} 10980-10012-19782-10988$.

Holzhauser H, Magny M and Zumbuhl HJ (2005) Glacier and lake-level variations in west-central Europe over the last 3500 years. The Holocene 15: 789-801.

Hughes MK and Diaz HF (1994) Was there a 'medieval warm period', and if so, where and when? Climatic Change 26: 109-142.

Lang G (1994) Quartäre Vegetationsgeschichte Europas. Methoden und Ergebnisse. Jena: G. Fischer.

Leighton R (1999) Sicily Before History: An Archaeological Survey from the Palaeolithic to the Iron Age. Cornell University Press.

Luterbacher J, García-Herrera R, Akcer-On S et al. (2012) 2 - A review of 2000 years of paleoclimatic evidence in the Mediterranean. In: Lionello P (ed.) The Climate of the Mediterranean Region. Oxford: Elsevier, pp. 87-185.

Mahood GA and Hildreth W (1986) Geology of the peralkaline volcano at Pantelleria, Strait of Sicily. Bulletin of Volcanology 48: 143-172.

Martin-Puertas C, Valero-Garces BL, Mata MP et al. (2008) Arid and humid phases in southern Spain during the last 4000 years: The Zonar Lake record, Cordoba. The Holocene 18: 907-921.

Moore PD, Webb JA and Collinson ME (1991) Pollen Analysis. Second Edition. London: Blackwell Scientific Publications.

Morellon M, Valero-Garces B, Vegas-Vilarrubia T et al. (2009) Lateglacial and Holocene palaeohydrology in the western Mediterranean region: The Lake Estanya record (NE Spain). Quaternary Science Reviews 28: 2582-2599.

Moreno A, Perez A, Frigola J et al. (2012) The Medieval Climate Anomaly in the Iberian Peninsula reconstructed from marine and lake records. Quaternary Science Reviews 43: 16-32.

Moreno JM, Vázquez A and Vélez R (1998) Recent history of forest fires in Spain. In: Moreno JM (ed.) Large Fires. Leiden: Backhuys Publishers, pp. 159-185. 
Nicault A, Alleaume S, Brewer S et al. (2008) Mediterranean drought fluctuation during the last 500 years based on tree-ring data. Climate Dynamics 31: $227-245$.

Noti R, van Leeuwen JFN, Colombaroli D et al. (2009) Mid- and late-Holocene vegetation and fire history at Biviere di Gela, a coastal lake in southern Sicily, Italy. Vegetation History and Archaeobotany 18: 371-387.

Pausas JG and Fernández-Muñoz S (2012) Fire regime changes in the Western Mediterranean Basin: From fuel-limited to drought-driven fire regime. Climatic Change 110: 215-226.

Picon C, Guehl J and Ferhi A (1996) Leaf gas exchange and carbon isotope composition responses to drought in a drought-avoiding (Pinus pinaster) and a drought-tolerant (Quercus petraea) species under present and elevated atmospheric $\mathrm{CO}_{2}$ concentrations. Plant, Cell \& Environment 19 182-190.

Pirazzoli PA and Tomasin A (2003) Recent near-surface wind changes in the central Mediterranean and Adriatic areas. International Journal of Climatology 23: 963-973.

Punt W (1976) Northwest European Pollen Flora. Amsterdam: Elsevier, 145 pp.

Reille M (1992) Pollen et spores d'Europe et d'Afrique du nord. Marseille: Laboratoire de Botanique hostorique et Palynologie.

Reimer PJ, Baillie MGL, Bard E et al. (2009) IntCal09 and Marine09 radiocarbon age calibration curves, 0-50,000 years cal BP. Radiocarbon 51: $1111-1150$.

Richardson DM and Rundel PW (1998) Ecology and biogeography of Pinus: An introduction. In: Richardson DM (ed.) Ecology and Biogeography of Pinus. Cambridge: Cambridge University Press, pp. 3-46.

Richter T and van der Gaast S (2006) The Avaatech XRF Core Scanner: Technical description and applications to NE Atlantic sediments. New Techniques in Sediment Core Analysis 267: 39-50.

Roberts N, Brayshaw D, Kuzucuoğlu C et al. (2011) The mid-Holocene climatic transition in the Mediterranean: Causes and consequences. The Holocene 21: 3-13.

Rühl J (2003) Vascular plant diversity in abandoned vine and caper cultures of Pantelleria island (Sicily) and conclusions for landscape conservation.
Diploma thesis, Faculty of Mathematics Ernst-Moritz-Arndt, University of Greifswld.

Schnurrenberger D, Russell J and Kelts K (2003) Classification of lacustrine sediments based on sedimentary components. Journal of Paleolimnology 29: $141-154$.

Smyth WH (1824) Memoir Descriptive of the Resources, Inhabitants and Hydrography of the Sicily and its Islands, Interspersed with Antiquarian and Other Notices. London: John Murray.

Sobrino CM, Ramil-Rego P, Gómez-Orellana L et al. (2005) Palynological data on major Holocene climatic events in NW Iberia. Boreas 34: 381-400.

Stockmarr J (1971) Tablets with spores used in absolute pollen analysis. Pollen et Spores 13: 615-621.

Taricco C, Ghil M, Alessio S et al. (2009) Two millennia of climate variability in the Central Mediterranean. Climate of the Past 5: 171-181.

Tinner W and Hu FS (2003) Size parameters, size-class distribution and areanumber relationship of microscopic charcoal: Relevance for fire reconstruction. The Holocene 13: 499-505.

Tinner W, van Leeuwen JFN, Colombaroli D et al. (2009) Holocene environmental and climatic changes at Gorgo Basso, a coastal lake in southern Sicily, Italy. Quaternary Science Reviews 28: 1498-1510.

Turner R, Roberts N and Jones M (2008) Climatic pacing of Mediterranean fire histories from lake sedimentary microcharcoal. Global and Planetary Change 63: 317-324.

Van Geel B (1986) Application of fungal and algal remains and other microfossils in palynological analyses. In: Berglund BE (ed.) Handbook of Holocene Palaeoecology and Palaeohydrology. Chichester: Wiley, pp. 497-505.

Vannière B, Power MJ, Roberts $\mathrm{N}$ et al. (2011) Circum-Mediterranean fire activity and climate changes during the mid-Holocene environmental transition (8500-2500 cal. BP). The Holocene 21: 53-73.

Vidakovic M and Soljan M (1991) Conifers: Morphology and Variation. Graficki Zavod Hrvatske Zagreb.

Whittle AW (1996) Europe in the Neolithic: The Creation of New Worlds. Cambridge University Press. 